\title{
Melatonin decreases in vitro viability and migration of spheres derived from CF41.Mg canine mammary carcinoma cells
}

\author{
Consuelo Serrano, Sofía Guzmán, Jose Ignacio Arias and Cristian Gabriel Torres (1)
}

\begin{abstract}
Background: Mammary cancer is a common disease affecting female dogs, where approximately $50 \%$ of the cases are malignant. There is a subpopulation of cancer cells with stem cell-like features within the tumour microenvironment, which can form in vitro spheres, cell structures that grow in anchor-free conditions. This cell population shows resistance to conventional antitumor treatments explaining in part the recurrence of some type of cancers. It has been previously reported that spheres derived from CF41.Mg canine mammary carcinoma cells exhibit several stemness features. Melatonin has shown antitumor effects on cancer mammary cells; nevertheless, its effects have been poorly evaluated on canine mammary cancer stem-like cells. In this regard, it has described that melatonin decreases the expression of OCT-4 in CMT-U2229 mammary cancer cells, a transcription factor that participates in the modulation of self-renewal and drug resistance in cancer stem-like cells. The aim of this study was to compare the effects of melatonin on viability and migration of canine mammary carcinoma CF41.Mg-spheres, and CF41.Mg-parental cells. CF41.Mg cells were grown in DMEM high-glucose medium containing 10\% bovine foetal serum. CF41.Mg-spheres were cultured in ultra-low attachment plates with serum-free DMEM/F12 containing several growth factors. Cell viability (MTS reduction) and migration (transwell) assays were conducted in presence of melatonin $(0.01,0.1$ or $1 \mathrm{mM})$.

Results: Melatonin decreased cell viability at $1 \mathrm{mM}(P<0.05)$, with a significant reduction in spheres compared to parental cells at 24 and $48 \mathrm{~h}(P<0.05)$. Cell migration was inhibited in response to non-cytotoxic concentration of melatonin $(0.1 \mathrm{mM})(P<0.05)$ in spheres and monolayer of cells, no significant differences were detected between both cell subtypes.

Conclusions: These results indicate that melatonin reduces viability and migration of CF41.Mg cells, where spheres exhibit greater sensitivity to the hormone. Thus, melatonin represents a valuable potential agent against mammary cancer cells, especially cancer stem-like cells.
\end{abstract}

Keywords: Canine cancer cells, Mammary cancer stem cells, Melatonin

\section{Background}

Mammary tumours represent the neoplasms most frequently diagnosed in reproductively intact female dogs $[1$, 2]. Surgery is the treatment of choice for this disease; however, this therapeutic option is not feasible in the case of non-resectable or metastatic tumours [3]. Adjuvant chemotherapy can be used as therapeutic alternative in cases of tumours with high probability of metastasis, however, some cancer cells may acquire resistance to commonly available

\footnotetext{
* Correspondence: crtorres@uchile.cl

Laboratory of Biomedicine and Regenerative Medicine, Department of Clinical Sciences, Faculty of Veterinary and Animal Sciences, Universidad de Chile, Santa Rosa 11735, 8820808 La Pintana, Chile
}

drugs [4], therefore it is relevant to seek novel therapeutic alternatives.

The existence of subpopulations of cancer cells with stemness features (cancer stem-like cells (CSC)), also called tumour-initiating cells, may partially explain some characteristics of tumour progression, such as neoplastic recurrence, metastasis and drug resistance [5]. Mammary CSC exhibit the capacity for self-renewal, chemo and radioresistance, vascular mimicry, invasiveness and $\mathrm{CD} 44^{+} / \mathrm{CD} 24^{-/ \text {low }}$ phenotype $[4,6]$. It is possible to obtain them in vitro from cell lines by means of the spheres-forming ability, which is one of the most used strategies to isolate and identify CSC [6].

(c) The Author(s). 2019 Open Access This article is distributed under the terms of the Creative Commons Attribution 4.0 International License (http://creativecommons.org/licenses/by/4.0/), which permits unrestricted use, distribution, and 
Spheres derived from canine mammary carcinoma cells CF41.Mg express in a high proportion the $\mathrm{CD} 44^{+} /$ CD24 $4^{-/ \text {low }}$ phenotype, in addition to other stemness characteristics such as self-renewal and relative chemoresistance to doxorubicin, paclitaxel and simvastatin [4]. On the other hand, CSC also express transcription factors associated with stemness, including OCT4, which plays a key role in carcinogenesis and provides a mechanism by which CSC could acquire or maintain a phenotype resistant to various therapies [7].

Melatonin (N-acetyl-5-methoxytryptamine) is an indole hormone synthesized by the mammalian pineal gland and other tissues such as retina, gastrointestinal tract, skin, among others [8, 9]. Physiological levels of melatonin in healthy dogs is dependent of diurnal cycle and season, rising during the night and in autumnwinter seasons. These plasma levels fluctuate between 2 and $13 \mathrm{pg} / \mathrm{ml}$, depending on the factors already mentioned [10, 11]. On tumour cells, this liposoluble hormone has pleiotropic effects including antioxidant, antiangiogenic, pro-apoptotic and antiproliferative effects through receptor-dependent and receptor-independent mechanisms [12, 13], nevertheless, its actions on CSC has been poorly studied [14]. Melatonin-receptors MT1 and MT2 are ubiquitous [15] G-protein-coupled receptors that once activated by their ligand induce an inhibition of adenylyl cyclase and cyclic AMP, which translates into antiproliferative effects [16-19]. Antitumour effects mediated by MT1-interaction correlate with antiestrogenic effects induced in oestradiol receptor type $\alpha(E R \alpha)$-positive mammary cancer cells, where melatonin represses the transcriptional activity of ER $\alpha$ (decreasing the phosphorylation of receptor and/or coactivator molecules) and inhibits aromatase activity [16, 17]. Thus, this hormone acts as an inhibitor of cell proliferation and an inducer of apoptosis, decreasing the mitogenic response of tumour cells to oestradiol [20]. In this regard, it has been described that melatonin reduces ER $\alpha$ and OCT4 expression and the binding of the ER $\alpha$ to OCT4, down-regulating sphere-forming ability in oestradiol-dependent cells, which suggest that this hormone could modulate self-renewal in CSC [21]. There is evidence that melatonin decreases OCT4 immunoexpression in spheroids derived from canine mammary cancer cells CMT-U2229 [7], which may partially explain the antiproliferative effect induced by this hormone on these cells $[7,13]$. Melatonin also decreases invasiveness ability of CMT-U2229-spheres and modulates epithelial-mesenchymal transition (EMT) [7]. Nevertheless, it is necessary to study its in vitro antitumor effects in other cell types that are more representative of mammary tumours and with higher malignancy. This is the case of CF41.Mg cell line, which exhibit an invasive and metastatic phenotype $[13,22]$. The aim of this work was to determine the in vitro effect of melatonin on the viability and migration of CSC derived from CF41.Mg canine mammary carcinoma cells.

\section{Results}

Viability of CF41.Mg cells was reduced $(P<0.05)$ in both monolayer $(53.4 \pm 9.9 \%$ of viability compared to control at $48 \mathrm{~h})$ and spheres $(52.1 \pm 15.8 \%$ and $25.4 \pm 6.7 \%$ compared to control at 24 and $48 \mathrm{~h}$ respectively) supplemented with $1 \mathrm{mM}$ melatonin. No significant differences were detected at lower concentrations $(0.01$ and $0.1 \mathrm{mM})$. When comparing the viability of both cultures in response to $1 \mathrm{mM}$ melatonin, spheres viability decreased more intensely $(P<$ 0.05 ) than monolayer of cells at both time points (Figs. 1 and 2). On the other hand, the number of migrating cells was reduced $(P<0.05)$ after $24 \mathrm{~h}$ of incubation in medium supplemented with of $0.1 \mathrm{mM}$ of melatonin (CF41.Mg = $81 \pm 37$; and CF41.Mg-spheres $=72 \pm 23$ ) compared to $0.01 \mathrm{mM}$ melatonin (CF41.Mg $=152 \pm 42$; and CF41.Mgspheres $=141 \pm 41)$ and vehicle $(C F 41 . M g=140 \pm 42$; and CF41.Mg-spheres = $146 \pm 25$ ) (Fig. 3). No significant differences were detected in the migration ability between monolayer and spheres.

\section{Discussion}

A key feature of CSCs is its potential to resist conventional anti-tumour chemo and radiotherapy, a condition already observed in CSCs derived from canine mammary cancer $[5,6]$. It is well known that chemo-resistance is acquired by a variety of mechanisms including high expression and function of multidrug-resistance (MDR) transport proteins involved in the excretion of xenobiotics [4]. In accordance with previous studies [9, 12, 13], our data indicates that melatonin supplementation in culture medium decreases viability and migration of CF41.Mg cells at concentrations of 1 and $0.1 \mathrm{mM}$ respectively, being its greatest effect on CSC viability. There is currently little evidence on the effect of melatonin on CSC biology and the mechanism of action involved; however, it has been suggested that this hormone may target the transcription factor OCT4 [7], modifying its function on self-renewal, pluripotency and drug resistance [21].

There is evidence that CSCs is a heterogeneous population where two morphological patterns are recognized, one mesenchymal (exhibiting a CD $44^{+} / \mathrm{CD} 24^{-/ \text {low }}$ phenotype) and another epithelial ( $\mathrm{ALDH}^{+}$phenotype). The first, usually is in a quiescent state and can be induced by oxidative stress, which can be pharmacologically modulated. In contrast, epithelial-CSCs are in a more proliferative state $[23,24]$. Data of our lab suggest that CF41.Mg-spheres exhibit a mesenchymal phenotype (CD $44^{+} / \mathrm{CD} 24^{-/ \text {low }}$ phenotype, low proliferative rate) [4], condition that may be inhibited by melatonin, since its 

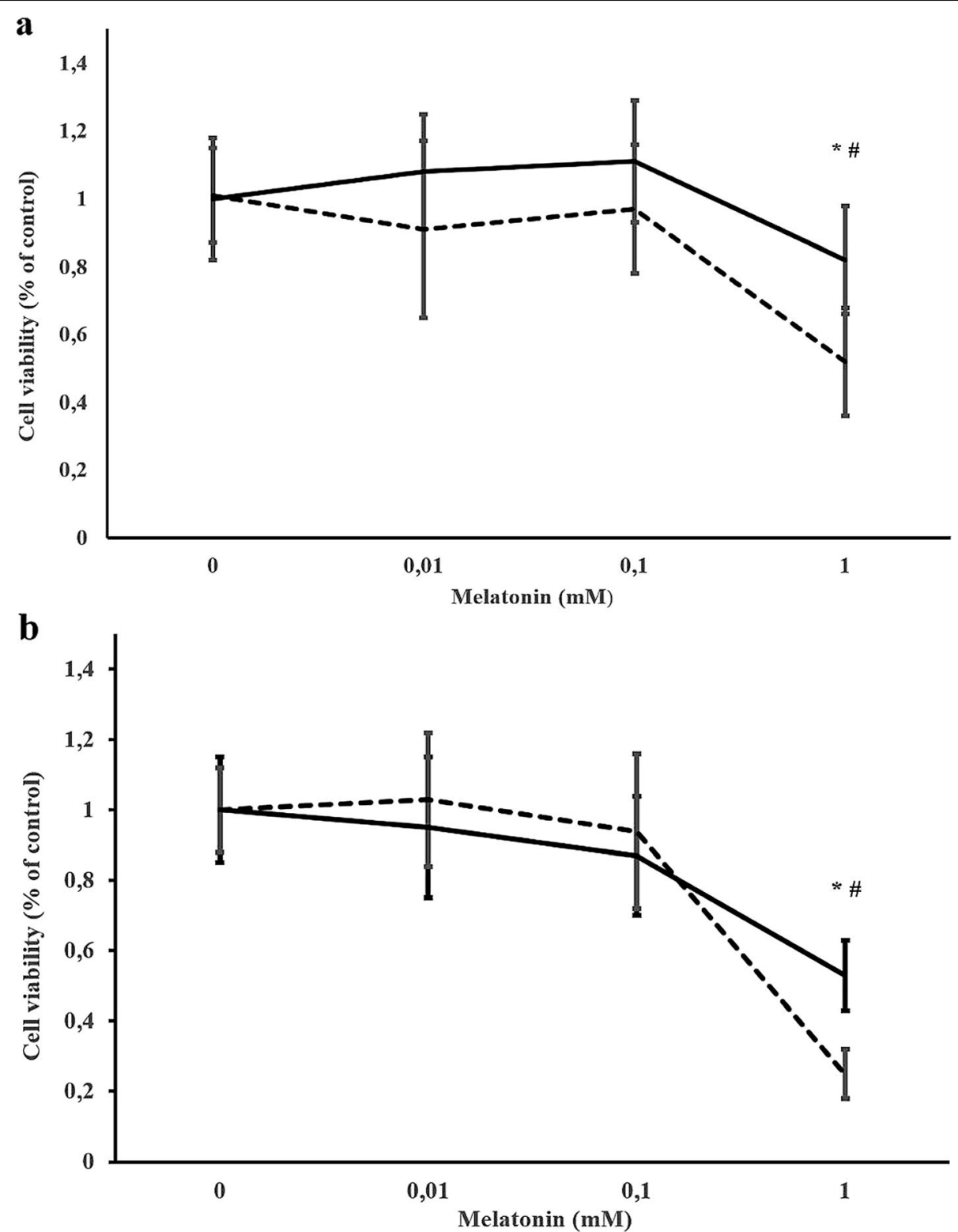

Fig. 1 Melatonin decreases viability of spheres derived from CF41.Mg canine mammary carcinoma cells. CF41.Mg cells in monolayer (solid line) and CF41.Mg-spheres (dashed line) were treated with different concentrations (0-1 mM) of melatonin for 24 (a) and 48 (b) h. The proportion of viable cells was determined by MTS assay. Values are mean \pm SD of 3 individual experiments in triplicate. ${ }^{*} P<0.05$ when comparing different experimental groups; ${ }^{\#} P<0.05$ when comparing both types of cultures

antioxidant effect [12], explaining in part the cell viability data shown here. As just described, it has reported that melatonin decreases E-cadherin and increases vimentin and $\mathrm{N}$-cadherin expression in both canine and human mammary tumour cells (CMTU229 and MCF7 respectively), inducing an antiinvasive effect in these cells [7]. It is relevant to consider that CMT-U229 is a cell line derived from a benign mixed mammary tumour [13], unlike CF41.Mg cell line used in this study, which is representative of high histological and metastatic canine mammary tumours $[13,22]$. Thus, overall our data and previously reported information suggest that melatonin exerts an antiproliferative effect on canine mammary CSCs.

In general, exogenous administration of melatonin is safe in dogs because it almost does not induce side effects, although the hormone can cause sedation in a low proportion of animals [25]. In humans, oral melatonin improves non-restorative sleep and circadian rhythm amplitudes [26], therefore the pharmacological use of this hormone seems innocuous. 


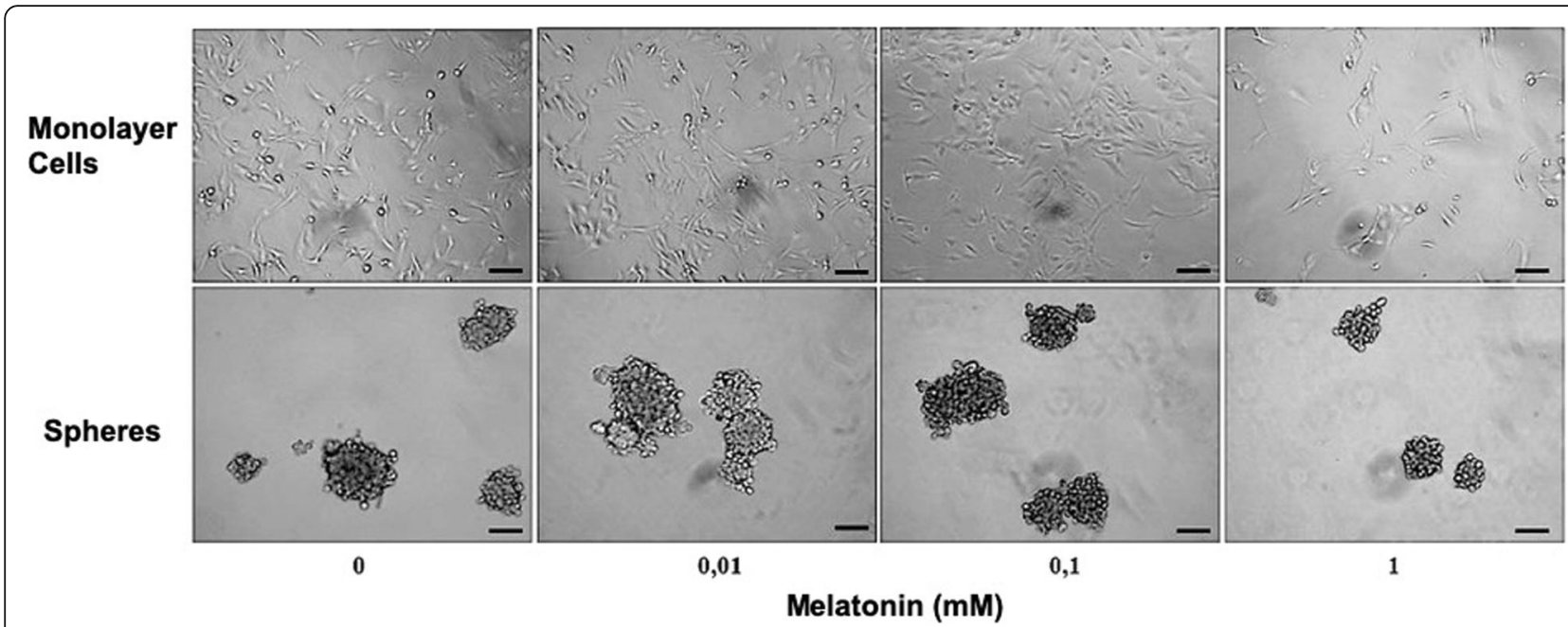

Fig. 2 Representative photomicrographs of effect of melatonin (0-1 mM) on CF41.Mg monolayer cells and spheres viability at $48 \mathrm{~h}$. Scale bar: $100 \mu \mathrm{m}$

Melatonin may represent a promising adjuvant option against high malignancy canine mammary carcinomas, nevertheless, it is necessary to outspread these analyses to other mammary tumour cells. Additional in vitro studies with lower concentrations of melatonin that mimic the plasma concentration achieved in dogs receiving a routine therapeutic dose (total posology of 3-6 mg twice a day [25]) are required. It has described that melatonin plasma bioavailability is dose dependent [27], where the maximum plasma concentration reached after an oral dose of $2 \mathrm{mg}$ is $1.15 \pm 0.92 \mathrm{ng} / \mathrm{ml}$ [28].

Thereby, this study reinforces the in vitro therapeutic potential of melatonin, especially on cells that have a chemo-resistant phenotype.

\section{Conclusion}

Melatonin reduces viability and migration of CF41.Mg cells, where CF41.Mg-CSC exhibit a greater proliferative sensitivity to this hormone. Thus, melatonin may be considered a potential anti-tumour agent against canine mammary stem-like cells, which supports future clinical trials.

\section{Methods}

\section{Cell culture}

CF41.Mg canine mammary carcinoma cells (CRL-6232; $\mathrm{ATCC}^{\oplus}$, Manassas, VA, USA) were cultured in adherence conditions with high glucose-DMEM (4.5 g/L DGlucose; Hyclone, GE Healthcare Life Sciences, Logan, UT, USA) supplemented with $10 \%$ foetal bovine serum (FBS) (Hyclone, GE Healthcare Life Sciences, Logan, UT, USA), $100 \mu \mathrm{g} / \mathrm{mL}$ streptomycin, $100 \mathrm{IU} / \mathrm{mL}$ penicillin and $0.25 \mu \mathrm{g} / \mathrm{mL}$ amphotericin B. Spheres derived from CF41.Mg cells were grown in ultralow attachment plates (Corning, NY, USA) containing culture medium serum-free DMEM/F12 (Sigma-Aldrich, Saint Louis, MO, USA) plus $10 \mathrm{ng} / \mathrm{mL}$ basic fibroblastic growth factor (bFGF) (Life Technologies Corp, Carlsbad, CA, USA) $10 \mathrm{ng} / \mathrm{mL}$ epidermal growth factor (EGF) (Life Technologies Corp, Carlsbad, CA, USA), $5 \mu \mathrm{g} / \mathrm{mL}$ insulin (Sigma-Aldrich, Saint Louis, MO, USA), $4 \mu \mathrm{g} / \mathrm{mL}$ heparin (Sigma-Aldrich, Saint Louis, MO, USA), 2\% B27 (Life Technologies Corp, Carlsbad, CA, USA) and, $20 \mu \mathrm{g} / \mathrm{ml}$ penicillin, $20 \mu \mathrm{g} / \mathrm{mL}$ streptomycin and $0.05 \mu \mathrm{g} /$ $\mathrm{mL}$ amphotericin B (Corning, NY, USA). All cultures were maintained in a humidified atmosphere with 5\% $\mathrm{CO}_{2}$ at $37^{\circ} \mathrm{C}$.

\section{Viability assay}

CF41.Mg cells $\left(2 \times 10^{3}\right.$ cells/well into 96-well plates $)$ and CF41.Mg-spheres $\left(5 \times 10^{3}\right.$ cells/well into non-adherent 96 well plates) were seeded in triplicate. After $24 \mathrm{~h}$, cells were incubated for 24 and $48 \mathrm{~h}$ in culture medium supplemented increasing concentrations of melatonin $(0.01,0.1,1 \mathrm{mM})$ (Selleckchem, Houston, TX, USA). In order to determine the viability, cells were exposed to 3-(4,5-dimethylthiazol-2-yl)-5(3-carboxymethoxyphenyl)-2-(4-sulfophenil)-2H-tetrazolium (MTS) for $3 \mathrm{~h}$ at $37^{\circ} \mathrm{C}$ and the retained dye was measured with a microplate reader (Biotek Instruments, Winoosky, VT, USA) at $490 \mathrm{~nm}$. Cell viability, referred to as the proportion of live cells at the end of the experiment, was calculated as a relative value in relation to the non-stimulated control, where the control group was considered to be $100 \%$ viability. Three independent experiments were performed.

\section{Migration assay}

Migration assays were carried out using Costar migration chambers (Transwell ${ }^{\bullet} 8-\mu \mathrm{m}$ pore size, 24-wells; Costar, Kennebunk, ME, USA). CF41.Mg monolayer cells and spheres $\left(5 \times 10^{4}\right)$ were incubated in presence of 0 , 


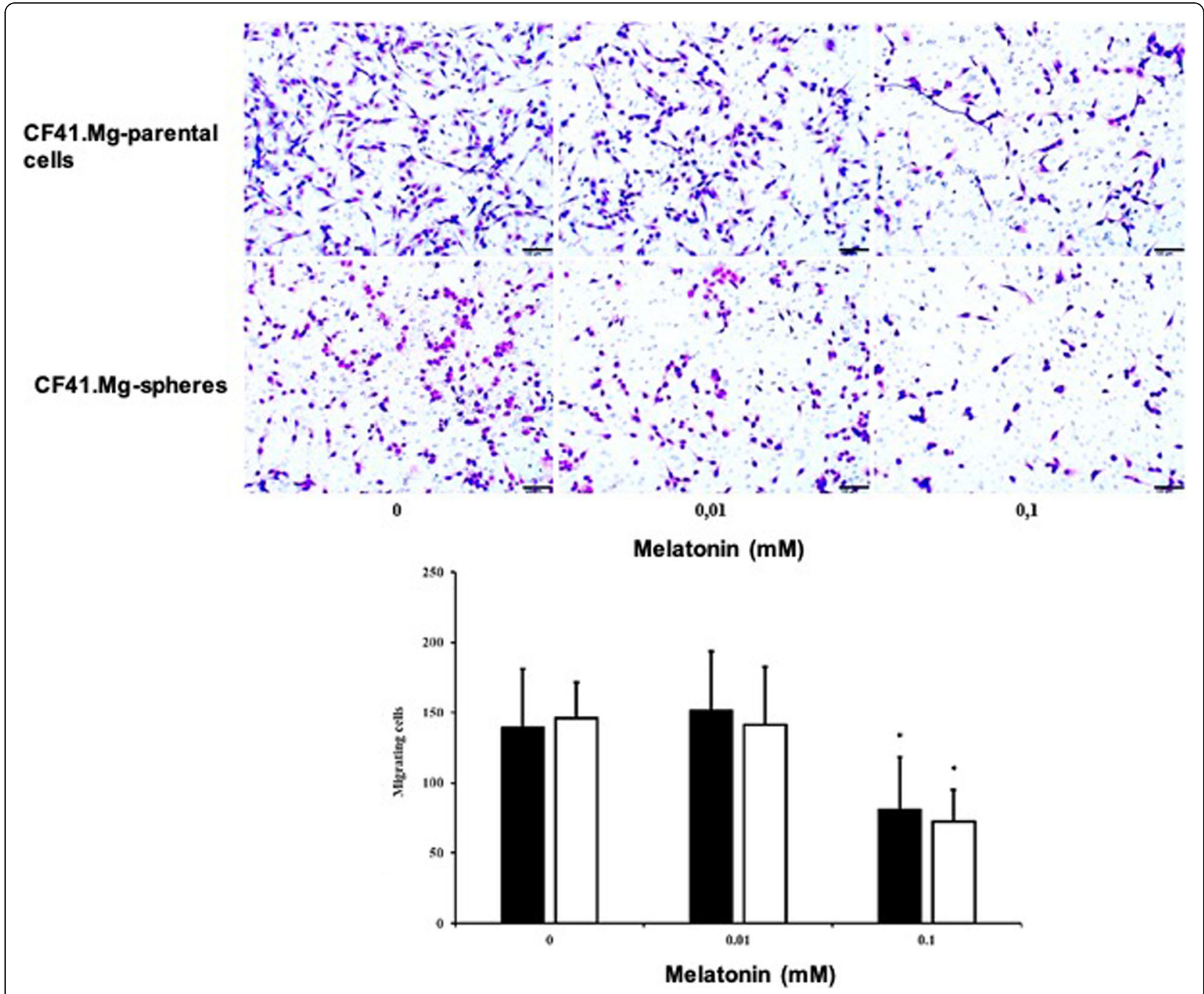

Fig. 3 Melatonin decreases migration ability of spheres derived from CF41.Mg canine mammary carcinoma cells. Representative photomicrographs of migration ability in CF41.Mg monolayer of cells and CF41.Mg-spheres in response to non-cytotoxic concentrations of melatonin (0-0.1 mM) for $24 \mathrm{~h}$. The migrating cells were stained with Giemsa and counted in a light microscope. Scale bars: $100 \mu \mathrm{m}$. Histogram quantifies migrating CF41.Mg cells (black) and CF41-Mg-spheres (white). Means \pm SD of three independent transwells in duplicate. ${ }^{*} P<0,05$ compared with the control cells

$0.01,0.1 \mathrm{mM}$ melatonin for $24 \mathrm{~h}$ in duplicate against a gradient of $5 \%$ FBS. Non-migrating cells were wiped from the upper side of the transwell membrane, and the migrating cells were fixed with cold methanol, and stained with Giemsa $1 \%$. Six fields were randomly selected and counted in each transwell under a light microscope at 10x magnification. Three independent experiments were carried out.

\section{Statistical analysis}

The Shapiro-Wilk test was used to determine data normality. ANOVA and Bonferroni or Kruskal Wallis tests were carried out to determinate differences between experimental groups. Mann-Whitney $U$ test was used to define differences between cell subtypes. A value of $P<$
0.05 was considered statistically different. Data was analysed using Infostat statistical software (Córdoba, Argentina).

\section{Abbreviations}

ALDH: Aldehyde dehydrogenase; AMP: Adenosine monophosphate; ANOVA: Variance analysis; B27: Neuronal cell culture serum-free supplement; bFGF: Basic fibroblastic growth factor; CD24: Heat stable antigen CD24; CD44: Homing cell adhesion molecule; CSC: Cancer stem-like cells; DMEM: Dulbecco's modified eagle medium; EGF: Epidermal growth factor; ERa: Oestradiol receptor a; FBS: Foetal bovine serum; MDR: Multidrug resistance; MT: Melatonin receptor; MTS: (3-(4,5-dimethylthiazol-2-yl)-5-(3carboxymethoxyphenyl)-2-(4-sulfophenyl)-2H-tetrazolium); OCT4: Octamerbinding transcription factor 4

\section{Acknowledgements}

We thank Dr. Pamela Cruz and Dr. Oscar A. Peralta for their technical assistance. 


\section{Authors' contributions}

CS carried out all experiments (cell viability and migration assays) and formal analysis of data. SG contributed with cell culture and migration assays. JIA helped with data analysis and drafted the manuscript. CGT designed the study, performed interpretation of results and wrote the manuscript. All authors have read and approved the final version of the manuscript.

\section{Funding}

This study was sponsored partially by FONDECYT grant 11110148 of CONICYT Chile, which allowed to collect and analyse of data shown here.

\section{Availability of data and materials}

The datasets used and/or analyzed during the current study are available from the corresponding author on reasonable request.

\section{Ethics approval and consent to participate}

This study did not require official or institutional ethical approval.

\section{Consent for publication}

Not applicable.

\section{Competing interests}

The authors declare that they have no competing interests. Melatonin was purchased from Selleckchem (Houston, TX, USA) and this company was not involved in this work.

Received: 15 March 2019 Accepted: 14 October 2019

Published online: 04 November 2019

\section{References}

1. Salas Y, Marquez A, Diaz D, Romero L. Epidemiological study of mammary tumors in female dogs diagnosed during the period 2002-2012: a growing animal health problem. PLoS One. 2015:10:e0127381.

2. Sorenmo KU, Rasotto R, Zappulli V, Goldschmidt MH. Development, anatomy, histology, lymphatic drainage, clinical features, and cell differentiation markers of canine mammary gland neoplasms. Vet Pathol. 2011:48:85-97

3. De Campos CB, Lavalle GE, Monteiro LN, Pêgas GRA, Fialho SL, Balabram D, et al. Adjuvant thalidomide and metronomic chemotherapy for the treatment of canine malignant mammary gland neoplasms. In Vivo. 2018;32: 1659-66.

4. Torres C, Olivares A, Stoore C. Simvastatin exhibits antiproliferative effects on spheres derived from canine mammary carcinoma cells. Oncol Rep. 2015;33:2235-44

5. Rybicka A, Król M. Identification and characterization of cancer stem cells in canine mammary tumors. Acta Vet Scand. 2016:58:86.

6. Michishita M, Akiyoshi R, Yoshimura H, Katsumoto T, Ichikawa H, OhkusuTsukada $\mathrm{K}$, et al. Characterization of spheres derived from canine mammary gland adenocarcinoma cell lines. Res Vet Sci. 2011;91:254-60.

7. Gonçalves Ndo N, Colombo J, Lopes JR, Gelaleti GB, Moschetta MG, Sonehara NM, et al. Effect of melatonin in epithelial mesenchymal transition markers and invasive properties of breast cancer stem cells of canine and human cell lines. PLoS One. 2016:11:e0150407.

8. Sánchez-Barceló EJ, Cos S, Fernández R, Mediavilla. Melatonin and mammary cancer: a short review. Endocr Relat Cancer. 2003;10:153-9.

9. Li Y, Li S, Zhou Y, Meng X, Zhang JJ, Xu DP, et al. Melatonin for the prevention and treatment of cancer. Oncotarget. 2017:8:39896-921.

10. Zań RS, Roliński Z, Kowalski CJ, Bojarska-Junak A, Madany J. Diurnal and seasonal changes in endogenous melatonin levels in the blood plasma in dogs. Pol J Vet Sci. 2013;16:759-61.

11. Thomovsky SA, Chen AV, Deavila DM, Kiszonas AM. Serum melatonin values in normal dogs and dogs with seizures. J Am Anim Hosp Assoc. 2019;55:78-82.

12. Di Bella G, Mascia F, Gualano L, Di Bella L. Melatonin anticancer effects: review. Int J Mol Sci. 2013;14:2410-30

13. Gelaleti GB, Borin TF, Maschio-Signorini LB, Moschetta MG, Hellmén E, Viloria-Petit AM, et al. Melatonin and IL-25 modulate apoptosis and angiogenesis mediators in metastatic (CF-41) and non-metastatic (CMTU229) canine mammary tumour cells. Vet Comp Oncol. 2017;15:1572-84.
14. Asghari MH, Ghobadi E, Moloudizargari M, Fallah M, Abdollahi M. Does the use of melatonin overcome drug resistance in cancer chemotherapy? Life Sci. 2018;196:143-55

15. Slominski RM, Reiter RJ, Schlabritz-Loutsevitch N, Ostrom RS, Slominski AT. Melatonin membrane receptors in peripheral tissues: distribution and functions. Mol Cell Endocrinol. 2012;351:152-66.

16. Hill SM, Belancio VP, Dauchy RT, Xiang S, Brimer S, Mao L, et al. Melatonin: an inhibitor of breast cancer. Endocr Relat Cancer. 2015;22:183-204.

17. Lopes J, Da Silva M, De Medeiros F, De Campos D. Evaluation of melatonin effect on human breast cancer stem cells using a three-dimensional growth method of mammospheres. Anti Cancer Agents Med Chem. 2017:17:961-5.

18. Nooshinfar E, Safaroghli-Azar A, Bashash D, Akbari ME. Melatonin, an inhibitory agent in breast cancer. Breast Cancer. 2017;24:42-51.

19. Ramos J, Bazela L, Victorasso B, Gobbe M, Carvalho L, Rodriguez G, et al. Evaluation of melatonin treatment in primary culture of canine mammary tumors. Oncol Rep. 2015:33:311-9.

20. Luzía E, Honrio-Franca A, Trinidade Da Silva R, Ferreira C, Souza C, Pilla F. The effect of melatonin adsorbed to polyethylene glycol microspheres on the survival of MCF-7 cells. Neuroimmunomodulation. 2015;23:27-32.

21. Lopes J, Arnosti D, Trosko J, Tai M, Zuccari D. Melatonin decreases estrogen receptor binding to estrogen response elements sites on the OCT4 gene in human breast cancer stem cells. Genes Cancer. 2016;7:209-17.

22. Saito T, Dai T, Asano R. The hyaluronan synthesis inhibitor 4methylumbelliferone exhibits antitumor effects against mesenchymal-like canine mammary tumor cells. Oncol Lett. 2013;5:1068-74.

23. Liu S, Cong Y, Wang D, Sun Y, Deng L, Liu Y, et al. Breast cancer stem cells transition between epithelial and mesenchymal states reflective of their normal counterparts. Stem Cell Rep. 2014;2:278-91.

24. Luo M, Shang L, Brooks MD, Jiagge E, Zhu Y, Buschhaus JM, et al. Targeting breast cancer stem cell state equilibrium through modulation of redox signaling. Cell Metab. 2018;28:69-86.

25. Plumb D. Plumb's veterinary drug handbook. 7th ed. Stockholm: PharmaVet Inc.; 2011.

26. Zisapel N. New perspectives on the role of melatonin in human sleep, circadian rhythms and their regulation. Br J Pharmacol. 2018:175:3190-9.

27. Yeleswaram K, McLaughlin LG, Knipe JO, Schabdach D. Pharmacokinetics and oral bioavailability of exogenous melatonin in preclinical animal models and clinical implications. J Pineal Res. 1997;22:45-51.

28. Zhao H, Wang $Y$, Jin $Y$, Liu S, Xu H, Lu X. Rapid and sensitive analysis of melatonin by LC-MS/MS and its application to pharmacokinetic study in dogs. Asian J Pharmaceutical Sci. 2016;11(2):273-80.

\section{Publisher's Note}

Springer Nature remains neutral with regard to jurisdictional claims in published maps and institutional affiliations.

Ready to submit your research? Choose BMC and benefit from:

- fast, convenient online submission

- thorough peer review by experienced researchers in your field

- rapid publication on acceptance

- support for research data, including large and complex data types

- gold Open Access which fosters wider collaboration and increased citations

- maximum visibility for your research: over $100 \mathrm{M}$ website views per year

At BMC, research is always in progress.

Learn more biomedcentral.com/submissions 